НАУКОВИЙ ВІСНИК

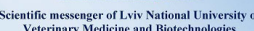

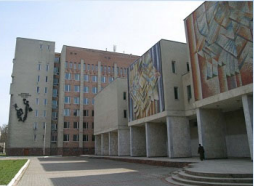

СЕРЯя: ВЕТТРИНАРН НАУКИ

Том 22 № 100

2020
Науковий вісник Дьвівського національного університету ветеринарної медицини та біотехнологій імені С.3. Гжицького. Серія: Ветеринарні науки

\author{
Scientific Messenger of Lviv National University \\ of Veterinary Medicine and Biotechnologies. \\ Series: Veterinary sciences
}

UDC 619:616.9:616.155.392:636.2

\title{
Pathogenetic aspects of rabbits' experimental infection caused by bovine leukemia virus
}

T. A. Romanishina ${ }^{1}$, D. V. Feschenko ${ }^{1}$, G. O. Rinyak ${ }^{2}$, V. V. Honcharenko ${ }^{1}$, A. A. Macibora ${ }^{1}$, I. O. Kaminska ${ }^{1}$, K. P. Sviridyuk ${ }^{3}$, A. P. Sviridyuk ${ }^{3}$

${ }^{1}$ Polissia National University, Zhytomyr, Ukraine

${ }^{2}$ Zhytomyr Regional State Laboratory of the State Service of Ukraine for Food Safety and Consumer Protection, Zhytomyr, Ukraine

${ }^{3}$ Zhytomyr Ivan Franko State University, Zhytomyr, Ukraine

Article info

Received 22.09.2020

Received in revised form 21.10.2020

Accepted 22.10.2020

Polissia National University Stary Boulevard, 7, Zhytomyr, 10008, Ukraine.

Tel.: +38-097-356-27-07

E-mail:tveterinar@gmail.com

Zhytomyr Regional State Laboratory of the State Service of Ukraine for Food Safety and Consumer Protection

Korostyshivska Str., 54, Zhytomyr 10007, Ukraine.

Zhytomyr Ivan Franko State University, Velyka Berdychivska Str., 40, Zhytomyr, 10008, Ukraine.
Romanishina, T. A., Feschenko, D. V., Rinyak, G. O., Honcharenko, V. V., Macibora, A. A., Kaminska, I. O., Sviridyuk, K. P., \& Sviridyuk, A. P. (2020). Pathogenetic aspects of rabbits' experimental infection caused by bovine leukemia virus. Scientific Messenger of Lviv National University of Veterinary Medicine and Biotechnologies. Series: Veterinary sciences, 22(100), 1622. doi: 10.32718/nvlvet10003

Bovine leukemia virus (BLV) is an infectious disease of cattle, causing high economic losses worldwide, especially in the field of dairy farming. There is no common vision on the problem of interspecies transmission of BLV. Therefore, a detailed study of the etiologic relationship between leukemia in cattle and other animal species is relevant. Various laboratory animal models provide insight into the pathogenesis of viral infections. The article presents the research results of two series rabbits' intravenous infection with bovine leukemia virus (BLV) using the culture antigen FLK-BLV and the blood of rabbits with clinical, hematological and immunological signs of viral tumor growth. Blood from all animals was taken from the ear vein after 14, 21, 30 days, and then monthly for six months: to study the morphological parameters of blood and to determine the titer of antibodies to BLV. Blood serum for the presence of antibodies to BLV was examined using a diagnostic kit for the indication of animals infected with the leukemia virus in an immunodiffusion reaction produced by LLC "SRE Veterinary Medicine", Kharkiv. It was found that the stage of the BLV provirus in the blood leukogram of infected animals was characterized by pronounced lymphocytosis on the 21st day of the experiment. The highest concentration of antibodies to BLV in the blood serum was found on the 90th day after the administration of the virus-containing material, which disappeared from the blood on the 150-180th day after infection. In experimental rabbits, after five months for thirty days, in the absence of antibodies to leukemia in the blood serum, multiple tumors of a dense consistency began to develop throughout the body. Such clinical signs and changes in the of rabbits' blood of the experimental group are characteristic of serologically positive cows on the hematological development stage of leukemic process and correlate with the results of domestic and foreign authors. The presence of a large number of lymphoblasts, as well as leukolysis cells, in the histological preparation of lymph nodes, lungs, heart and the accumulation of lymphocytes' immature forms around the interlobular vessels of the liver, which were found in pathohistological studies of the experimental rabbits' organs, may indicate the development of the leukemia process on early stage in them. The results obtained indicate the ability of BLV to overcome successfully the interspecies barrier upon parenteral ingestion of heterologous individuals from infected lymphocytes and in the form of a culture antigen.

Key words: FLK-BLV cell culture, rabbits, experimental infection, hematological parameters, antibody titer, histological change.

\section{Патогенетичні аспекти експериментальної інфекції кролів, зумовленої вірусом лейкозу великої рогатої худоби}


Т. О. Романишина ${ }^{1}$, Д. В. Фещенко ${ }^{1}$, Г. О. Риняк ${ }^{2}$, В. В. Гончаренко ${ }^{1}$, А. . $\quad 1$, І. $\quad 1$, К. П. Свиридюк ${ }^{3}$, А. П. Свиридюк ${ }^{3}$

${ }^{1}$ Поліський національний університет, м. Житомир, Украӥна

${ }^{2}$ Регіональна державна лабораторія державної служби Украӥни з питань безпечності харчових продуктів та захисту споживачів, м. Житомир, Украӥна

${ }^{3}$ Житомирський державний університет імені Івана Франка, м. Житомир, Украӥна

Лейкоз великої рогатої худоби (BLV) - інфекиійна хвороба великої рогатої худоби, яка спричиняє високі економічні збитки в усьому світі, особливо у галузі молочного скотарства. Не існує єдиного погляду на проблему міжвидової передачі BLV, тому актуальним є детальне вивчення етіологічного зв'язку між лейкозом великої рогатої худоби та іниих видів тварин. Моделі різних лабораторних тварин дозволяють зрозуміти патогенез вірусних інфекиій. У статті наведено результати досліджень двох серій внутрішньовенного зараження кролів вірусом лейкозу великої рогатої худоби (BLV) з використанням культурального антигену FLK-BLV та крові кролів з клінічними, гематологічними та імунологічними ознаками вірусного пухлинного росту. Кров від усіх тварин відбирали з вушної вени через 14, 21, 30 діб, а потім щомісяия протягом пів року: для дослідження морфологічних показників крові та для визначення титру антитіл до BLV. Сироватку на наявність антитіл крові до BLV досліджували з використанням діагностичного набору для індикаиії інфікованих вірусом лейкозу тварин у реакиії імунодифузї виробництва ТОВ "НДП "Ветеринарна медицина" (м. Харків). Встановлено, що стадія провірусу BLV в лейкограмі крові заражених тварин характеризувалась вираженим лімфоцитозом на 21 добу експерименту. Найвища концентрація антитіл до BLV у сироватиі крові виявлялась на 90-y добу після введення вірусовмісного матеріалу, які зникали з крові на 150-180 добу після зараження. У експериментальних кролів через n'ять місяиів протягом тридияти днів при відсутності антитіл до лейкозу в сироватці крові, на всьому тілі почали розвиватися множинні пухлини шільної консистенції. Такі клінічні ознаки та зміни в крові кролів дослідної групи характерні для серологічно позитивних корів на гематологічній стадії розвитку лейкозного процесу та корелюють із результатами вітчизняних та закордонних авторів. Наявність великої кількості лімфобластів, а також клітин лейколізу в гістопрепаратах лімфатичних вузлів, легень, серия і скупчення незрілих форм лімфочитів навколо міжчасточкових судин печінки, виявлені у патогістологічних дослідженнях органів експериментальних кролів, можуть свідчити про розвиток у них ранньої стадії лейкозного процесу. Отримані результати свідчать про здатність BLV успішно долати міжвидовий бар'єр при парентеральному потраплянні в організм гетерологічних особин з інфікованих лімфочитами та у вигляді культурального антигену.

Ключові слова: Bovine leukemia virus (BLV), культура клітин FLK-BLV кролі, експериментальне зараження, гематологічні показники, титр антитіл, гістологічні зміни.

\section{Вступ}

Лейкоз великої рогатої худоби (Bovine leukemia virus (BLV)) - інфекційна хвороба великої рогатої худоби, яка зумовлює значні економічні збитки в країнах 3 розвинутим скотарством через втрати у виробництві молочної та м'ясної продукції (Trono et al., 2001; Rhodes et al., 2003; Murakami et al., 2011; Castellano \& Goizueta, 2014). В більшості країнах Свропейського союзу, Новій Зеландії та Австралії наприкінці 20 століття проведення чітких оздоровчих заходів щодо лейкемії корів було успішним (Nuotio et al., 2003; Acaite et al., 2007; Maresca et al., 2015; Sihvonen, 2015), на відміну від Аргентини, в якій протягом останніх 10 років через недосконалу систему протиепізоотичних заходів більше як 30 \% великої рогатої худоби приватного сектору і 80 \% молочних ферм 3 інтенсивним розвитком тваринництва уражені лейкозом (Trono et al., 2001; Lomonaco et al., 2014).

Інтенсивна динаміка передачі BLV зумовлена різними безконтрольними маніпуляціями, пов'язаними 3 взяттям крові, вакцинацією, кастрацією, ректальними дослідженнями тощо, а тварини 3 високим рівнем провірусу у крові і латентним перебігом хвороби $є$ одним з основних фактором передачі BLV (Kobayashi et al., 2020; Saldarriaga-Saldarriaga et al., 2020). У 20 30 \% інфікованих тварин відсутні клінічні ознаки, але развивається стійкий лімфоцитоз, який характеризується постійним і стабільним збільшення циркулюючих периферичних клітин CD4 + IgM + (Hamilton et al., 2003; Alvarez et al., 2013; Barez et al., 2015).
Велика рогата худоба - основний природний резервуар BLV, однак тільки у 1-5 \% корів розвивається лімфома 3 летальним закінченням. Інші види тварин можуть бути експериментально інфіковані BLV різними клінічними, гематологічними та імунологічними проявами (Sentsui et al., 1988; Krasnikova et al., 2019; Porta et al., 2019). Важливе значення має питання про спільність лейкозу великої рогатої худоби та людини (Gao et al., 2020). Механізми трансформації клітин ретровірусами людини і тварин, очевидно, принципово не відрізняються. Саме неконтрольований пухлинний онкоріст $є$ типовою ознакою для лейкозу великої рогатої худоби. Проблема онкологічних захворювань у гуманній та ветеринарній медицині є актуальною вже десятки років (Buehring et al., 2019; Zyrianova et al., 2020). Постановка експериментів щодо відтворення природної патогенетичної дії вірусу на живий організм 3 подальшими лабораторно-морфологічними дослідженнями є важливою ланкою в організації “фундаменту" для синтезу необхідних генетичносупресивних противірусних складових препаратів. Вивчення вірусної інфекції на різних стадіях прояву під час всього перебігу хвороби можлива за використання моделей лабораторних тварин (Sentsui et al., 1988; Zyrianova et al., 2020). Проведення дослідів на великій рогатій худобі як лабораторній моделі наразі $\epsilon$ економічно невигідним та досить трудомістким.

Метою роботи було вивчити здатність вірусу BLV до інтеграції в клітини гетерологічного організму (на прикладі кролів) та дослідити перебіг патологічного процесу лейкозу в лабораторних умовах. 


\section{Матеріал і методи досліджень}

Дослідження проводили на базі віварію “Житомирської регіональної державної лабораторії Державної служби України з питань безпечності харчових продуктів та захисту споживачів" (м. Житомир) та у лабораторіях кафедр мікробіології, фармакології та епізоотології і анатомії та гістології Поліського національного університету (м. Житомир).

Для експерименту були сформовані контрольна i дослідна групи кролів масою 1,5-2 кг віком 3-4 місяці по 12 тварин в кожній. Зараження кролів дослідної групи проводили культурою клітин ембріона вівці (FLK-BLV), що продукує вірус лейкозу великої рогатої худоби 3 концентрацією клітин - 50 тис. в $1 \mathrm{~cm}^{3}$ (Porta et al., 2019). Тваринам контрольної групи нічого не вводили, а утримували в аналогічних умовах. Всі кролі були забезпечені збалансованим раціоном. Дослід тривав 6 місяців. Впродовж всього експерименту спостерігали за поведінкою кролів, проводили клінічний огляд, відбирали кров для морфологічних та імунологічних досліджень. Кролів забивали у віці 10 місяців, проводили їх розтин, вивчали патологоанатомічні зміни та відбирали матеріал для гістологічних досліджень.

Кров від усіх тварин відбирали з вушної вени через 14, 21, 30 діб, а потім щомісяця протягом пів року: для дослідження морфологічних показників - в одноразові вакуумні пробірки типу VACUETTE, які містили стабілізатор крові Na-ЕДТА, і для визначення титру антитіл до BLV - в одноразові шприци об'ємом $5 \mathrm{~cm}^{3}$. У стабілізованій крові визначали кількість лейкоцитів і їх морфологічний склад - маркерні показники BLV.

Сироватку крові досліджували на наявність антитіл до BLV з використанням діагностичного набору для індикації інфікованих вірусом лейкозу тварин у реакції імунодифузії виробництва ТОВ “НДП “Ветеринарна медицина” (м. Харків).
Від п’яти кролів дослідної групи з новоутвореннями на п’ятому місяці експерименту була відібрана кров $\left(2 \mathrm{~cm}^{3}\right)$ і введена П'яти здоровим кролям віком 3 місяці - для перевірки “заразності" пухлинного процесу з подальшим забором крові на 14 та 28 добу і дослідженням іï на наявність антитіл до BLV, визначенням якісного та кількісного складу лейкоцитів.

Через 6 місяців 7 кролів дослідної групи були забиті з подальшим проведенням розтину та відбором матеріалу для гістологічних досліджень. Умертвіння лабораторних тварин проводили згідно з Європейською конвенцією про захист хребетних тварин, що використовуються для дослідних та інших наукових цілей (1986 рік). Гістозрізи зафарбовували гематоксилін-еозином та вивчали за допомогою світлового мікроскопа (Ovcharenko et al., 2013).

\section{Результати досліджень}

У кролів контрольної групи протягом всього періоду експерименту не виявляли позитивної реакції в РІД, гематологічні показники залишались у межах фізіологічних норм.

Через 14 діб після введення інокуляту FLK-BLV у сироватках крові шести експериментальних кролів при серологічних дослідженнях були виявлені лінії преципітації між досліджуваною і позитивною сироваткою крові $з$ діагностичного набору, що свідчить про одночасну наявність у сироватці крові як антитіл, так і антигенів з відповідними паратопами та епітопами (Zyrianova et al., 2020). Через 30 днів після зараження додаткові лінії преципітації зникли, і антитіла до ретровірусу великої рогатої худоби виявлялись у сироватці крові всіх дослідних кролів при розведенні сироватки від 1:64 до нативного протягом 30-90 дня експерименту, на відміну від результатів дослідження крові кролів контрольної групи (табл. 1).

\section{Таблиця 1}

Динаміка титрів антитіл у дослідних кролів, визначена в РІД

\begin{tabular}{|c|c|c|c|c|c|c|c|c|c|}
\hline \multirow{3}{*}{ Групи } & \multirow{3}{*}{$\begin{array}{c}\text { № } \\
\text { тварини }\end{array}$} & \multicolumn{8}{|c|}{ Наявність ліній преципітації при різних розведеннях сироватки дослідних кролів } \\
\hline & & \multicolumn{8}{|c|}{ Термін досліджень, діб } \\
\hline & & 14 & 21 & 30 & 60 & 90 & 120 & 150 & 180 \\
\hline \multicolumn{2}{|c|}{ Контрольна група } & - & - & - & - & - & - & - & - \\
\hline \multirow{11}{*}{$\begin{array}{l}\text { Дослід- } \\
\text { на група }\end{array}$} & 1 & нативна & нативна & $1: 2$ & $1: 2$ & $1: 4$ & нативна & \multicolumn{2}{|c|}{ Не дослідж. } \\
\hline & 2 & - & нативна & $1: 2$ & нативна & $1: 4$ & $1: 2$ & нативна & - \\
\hline & 3 & - & $1: 2$ & $1: 16$ & $1: 8$ & $1: 16$ & & загинув & \\
\hline & 4 & - & - & $1: 4$ & $1: 4$ & $1: 2$ & - & - & - \\
\hline & 5 & - & нативна & $1: 8$ & $1: 16$ & $1: 64$ & $1: 32$ & - & Не дослідж. \\
\hline & 6 & нативна & нативна & $1: 16$ & $1: 32$ & $1: 16$ & $1: 8$ & - & Не дослідж. \\
\hline & 7 & - & - & $1: 4$ & $1: 8$ & $1: 32$ & - & - & - \\
\hline & 8 & - & нативна & $1: 4$ & $1: 16$ & $1: 32$ & - & - & - \\
\hline & 10 & нативна & $1: 4$ & $1: 8$ & $1: 16$ & нативна & - & - & Не дослідж. \\
\hline & 11 & - & $1: 4$ & $1: 16$ & $1: 8$ & нативна & - & - & - \\
\hline & 12 & - & $1: 16$ & $1: 8$ & $1: 4$ & $1: 2$ & - & - & - \\
\hline
\end{tabular}

Примітка: “-”-негативний результат в РІД 
Найвища концентрація антитіл у сироватці крові вивлялась на 90-у добу після введення вірусовмісного матеріалу; на 150-180 добу після зараження антитіла зникли з крові, що пов'язуємо з роллю імуноглобулінів класу $\mathrm{G}$ в процесах фіксації комплементу та опсонізуючих реакціях, які є обов'язковими під час нейтралізації антигенів, а не імуноглобулінів класу А як нейтралізаторів токсинів у перші дні введення інокуляту (Gulyukin et al., 2019).

Зміни морфологічного складу крові кролів, зумовлені дією культури клітин FLK-BLV, характеризуються тенденцією до збільшення кількості лейкоцитів iз вираженим лімфоцитозом уже на 21 добу після зараження. Через 60 днів після постановки експерименту виявлено достовірне наростання відносної кількості лімфоцитів, максимальний показник яких $(81 \pm 1,08 \%)$ реєструвався у кролів на 90 -у добу.

Одночасно зі збільшенням лімфоцитів у крові кролів виявляли тенденцію до збільшення кількості моноцитів 7,75 $\pm 0,25$ (P $\leq 0,001)$ через три місяці після початку експерименту. Так, на $30-$ у та 60-у доби досліду виявляли вірогідне збільшення кількості юних нейтрофілів на 60,36 \% та 47,62 \% відповідно з одночасним достовірним зменшенням кількості сегментоядерних нейтрофілів у 2-3 рази порівняно з показниками тварин контрольної групи (табл. 2).

Таблиця 2

Динаміка змін кількості лейкоцитів та морфологічного складу крові у кролів дослідної групи $(\mathrm{n}=12)$

\begin{tabular}{|c|c|c|c|c|c|c|c|c|}
\hline \multirow{2}{*}{\multicolumn{2}{|c|}{ Показники }} & \multicolumn{7}{|c|}{ Термін досліджень, діб } \\
\hline & & $\begin{array}{c}\text { До початку } \\
\text { експерименту }\end{array}$ & 30 & 60 & 90 & 120 & 150 & 180 \\
\hline \multicolumn{2}{|r|}{ Лейкоцити, Г/л } & $6,56 \pm 0,12$ & $\begin{array}{c}10,94 \pm 0,12 \\
* * *\end{array}$ & $\begin{array}{c}12,94 \pm 0,19 \\
* * *\end{array}$ & $\begin{array}{c}15,06 \pm 0,12 \\
* * *\end{array}$ & $\begin{array}{c}14,04 \pm 0,1 \\
* * *\end{array}$ & $\begin{array}{c}13,33 \pm 0,1 \\
* * *\end{array}$ & $\begin{array}{c}11,33 \pm 0,14 \\
* * *\end{array}$ \\
\hline \multirow{6}{*}{ 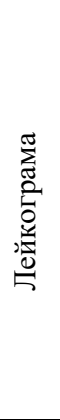 } & Лімфоцити & $68,50 \pm 0,87$ & $\begin{array}{c}66,25 \pm 0,65 \\
*\end{array}$ & $\begin{array}{c}74,75 \pm 1,11 \\
*\end{array}$ & $\begin{array}{l}81,0 \pm 1,08 \\
* * *\end{array}$ & $\begin{array}{c}80,67 \pm 1,1 \\
* * *\end{array}$ & $\begin{array}{c}77,17 \pm 0,8 \\
* * *\end{array}$ & $\begin{array}{l}75,67 \pm 0,88 \\
* *\end{array}$ \\
\hline & Моноцити & $4,25 \pm 0,25$ & $\begin{array}{l}2,25 \pm 0,29 \\
\quad * *\end{array}$ & $\begin{array}{c}5,25 \pm 0,29 \\
*\end{array}$ & $\begin{array}{l}7,75 \pm 0,25 \\
\quad * * *\end{array}$ & $\begin{array}{l}6,67 \pm 0,3 \\
\quad * * *\end{array}$ & $\begin{array}{l}7,25 \pm 0,58 \\
\quad * *\end{array}$ & $\begin{array}{c}5,33 \pm 0,33 \\
*\end{array}$ \\
\hline & Еозинофіли & $1,75 \pm 0,48$ & $\begin{array}{c}3,75 \pm 0,25 \\
*\end{array}$ & $\begin{array}{c}4,25 \pm 0,25 \\
* *\end{array}$ & $2,0 \pm 0,41$ & $2,33 \pm 0,33$ & $\begin{aligned} 3,33 & \pm 0,33 \\
& *\end{aligned}$ & $\begin{array}{c}4,33 \pm 0,33 \\
* *\end{array}$ \\
\hline & Базофіли & $0,75 \pm 0,25$ & $0,5 \pm 0,11$ & $0,75 \pm 0,25$ & $1,0 \pm 0,41$ & $0,67 \pm 0,23$ & $0,33 \pm 0,18$ & $0,33 \pm 0,13$ \\
\hline & $\begin{array}{c}\text { Нейтофіли } \\
\text { паличкоядерні }\end{array}$ & $2,75 \pm 0,25$ & $\begin{array}{c}6,75 \pm 0,25 \\
* * *\end{array}$ & $\begin{array}{c}5,25 \pm 0,25 \\
* * *\end{array}$ & $2,75 \pm 0,63$ & $2,33 \pm 0,33$ & $2,67 \pm 0,33$ & $3,67 \pm 0,67$ \\
\hline & $\begin{array}{c}\text { Нейтрофіли } \\
\text { сегменто ядерні }\end{array}$ & $22,0 \pm 0,41$ & $\begin{array}{c}20,5 \pm 0,29 \\
*\end{array}$ & $\begin{array}{l}9,75 \pm 0,48 \\
* * *\end{array}$ & $\begin{array}{l}5,5 \pm 0,87 \\
\quad * * *\end{array}$ & $\begin{array}{c}7,33 \pm 0,33 \\
* * *\end{array}$ & $\begin{array}{l}9,25 \pm 0,58 \\
* * *\end{array}$ & $\begin{array}{c}11,67 \pm 0,88 \\
* * *\end{array}$ \\
\hline
\end{tabular}

Якісний склад лімфоцитів також підлягав суттєвим змінам, а саме: характеризувався появою бласних та рідеровських клітин та клітин 3 подвійними ядрами. Такі зміни в лейкограмі кролів дослідної групи характерні для серологічно позитивних корів на гематологічній стадії розвитку лейкозного процесу та корелюють із результатами вітчизняних та закордонних авторів (Alvarez et al., 2013; Gulyukin et al., 2019; Porta et al., 2019; Zyrianova \& Kovalchuk, 2020).

У трьох кролів дослідної групи через 3 тижні після зараження погіршився апетит, спостерігалось пригнічення, виснаження, кон'юнктивіти, виснаження, але через два тижні вказані клінічні ознаки зникли у всіх тварин.

У п’яти інших кролів цієї ж групи через п'ять місяців при відсутності антитіл до лейкозу в сироватці крові на всьому тілі почали розвиватись множинні пухлини щільної консистенції протягом тридцяти днів (рис. 1).

Особливо виражені новоутворення були в ділянці лівої частини тіла на передній і задній кінцівках. У міру збільшення об'єму пухлин у кроля розвивалися набряки, тварина була пригнічена, апетит погіршився, рухи сповільнювались.

Через місяць після виникнення ознак пухлинного росту від кожного кроля була відібрана кров і введена здоровим молодим кролям. На 28-у добу після зараження у всіх заражених молодих кролів спостерігали анорексію, вони почали худнути, у сироватці крові з'явились антитіла до вірусу лейкозу, виявлені в РІД. На 14-у добу у периферичній крові трьох кролів і на 28-у добу у всіх тварин, підданих зараженню, виявляли лейкоцитоз, відсоток лімфоцитів підвищився до 90-95\%. Ще через 30 днів після зараження у кролів почали прогресувати паралічі кінцівок, тому вони були забиті для подальших патоморфологічних досліджень.

При патологоанатомічному розтині дослідних кролів були виявлені зміни в лімфовузлах, печінці, легенях, серці. Лімфатичні вузли у всіх дослідних тварин відрізнялись від лімфатичних вузлів інтактних тварин - рівномірно збільшені, з гладкою поверхнею, капсула легко знімалася. У трьох заражених кролів спостерігали гепато- та спленомегалію. 


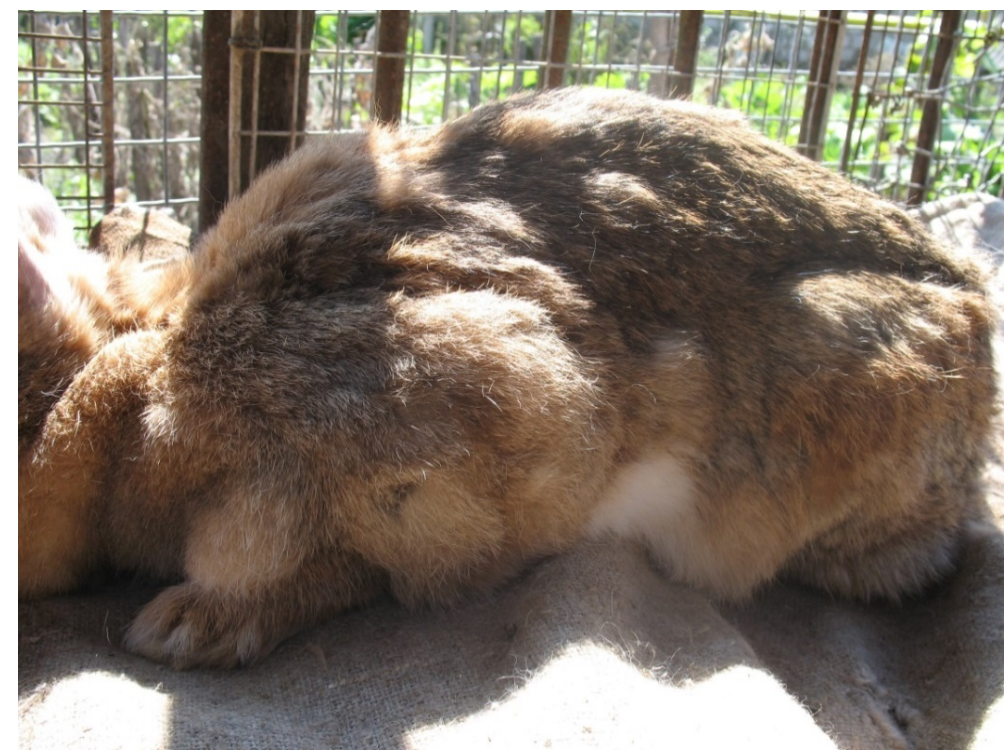

Рис. 1. Пухлини щільної консистенції кроля дослідної групи на п’ятий місяць експерименту

Зміни в печінці характеризувалися появою в синусоїдах більшої або меншої кількості лімфоїдних клітин, які розміщувалися у вигляді ланцюжків або невеликих скупчень. У ділянках міжчасточкової сполучної тканини

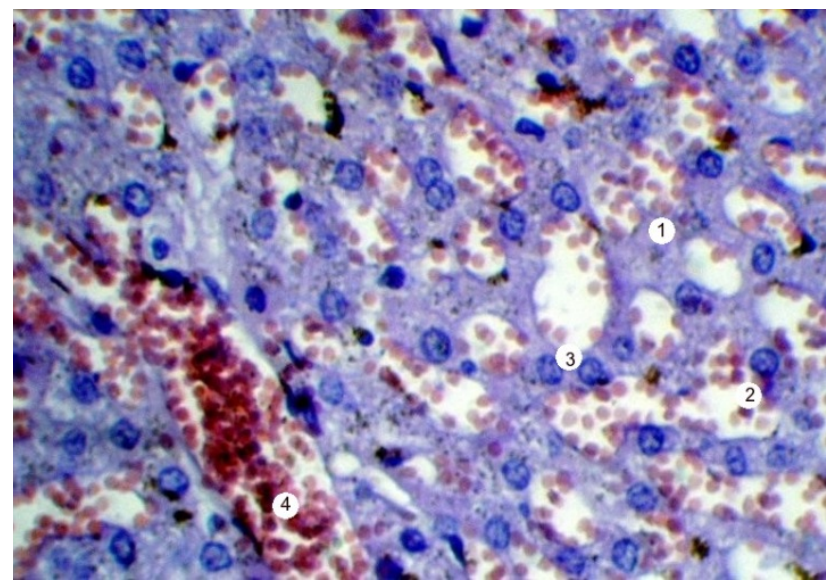

Рис. 2. Мікроскопічна будова печінки кроля третьої дослідної групи: 1 - гепатоцити; 2 - еритроцити; 3- лімфоїдні елементи; 4 - крововиливи. Гематоксилін та еозин. х 280

Скупчення лімфоїдних клітин на гістологічних препаратах міокарда виявлялись міжм'язевими волокнами у вигляді маленьких вогнищ. У кірковому шарі нирок утворювались дифузні розростання лімфоїдних елементів, серед яких - деформовані канальці у вигляді невеликих острівців епітеліальних клітин, що були у стані дистрофії (рис. 3).

Наявність великої кількості лімфобластів, а також клітин лейколізу в гістопрепаратах лімфатичних вузлів, легень, серця і скупчення незрілих форм лімфоцитів навколо міжчасточкових судин печінки, виявлені у патогістологічних дослідженнях органів експериментальних кролів, можуть свідчити про розвиток у них ранньої стадії лейкозного процесу. виявляли інфільтративні розростання неоднакової інтенсивності. При збільшенні х 280 виявилили гепатоцити 3 нехарактерною будовою, межа між якими згладжена (рис. 2).

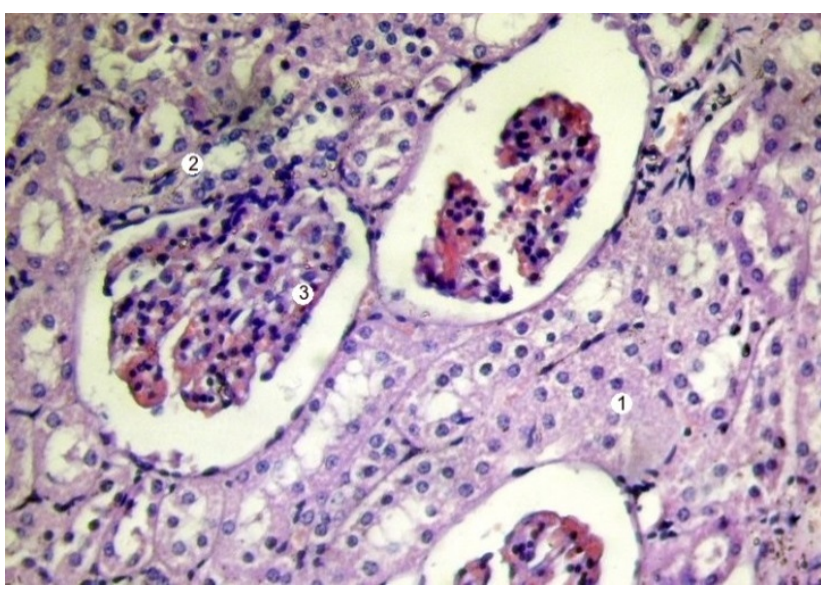

Рис. 3. Мікроскопічна будова нирки кроля дослідної

групи: 1 - лімфоїдні елементи; 2 - звивисті ниркові канальці; 3 - ниркові тільця. Гематоксилін та еозин. х 580

\section{Обговорення}

Як відомо, існують гомологічні та гетерологічні види тварин і саме на таких видах зазвичай проводять експериментальні роботи з відтворення лейкозу ВРХ. Наразі економічно доцільним $є$ пошук економічно зручної моделі для проведення експериментальної роботи щодо відтворення дії вірусу лейкозу ВРХ (Gulyukin et al., 2019, Krasnikova et al., 2019; Porta et al., 2019).

У кролів інфекційний процес, зумовлений вірусом лейкозу великої рогатої худоби, в більшості випадків характеризується появою специфічних антитіл і наявністю в крові геному BLV. В деяких випадках у тварин знижується Т-клітинна чутливість до стимуляції фітолектином і ознаки конюнктивіту, риніту, втрати 
живої маси (Gulyukin et al., 2019; Krasnikova et al., 2019). Експериментально підтверджено 100 \% можливість зараження лейкозом великої рогатої худоби кролів - виду, філогенетично цілком віддаленого від природного господаря цього вірусу, причому не тільки при параентеральному введенні крові інфікованої тварини, а й з молоком - через шлунково-кишковий тракт (Sentsui et al., 1988; Shabeykin et al., 2019).

У щурів та свиней експериментальна інфекція зумовлює появу імуноглобулінів щодо антигену BLV(Alvarez et al., 2013; Krasnikova et al., 2019). У курей антитіла можуть бути виявлені у всіх заражених птахів, і тільки в деяких з них развивається лейкемія (Martínez et al., 2014). У кіз развиваются стійкі гамаглобуліни, які забезпечують стійкість кіз до пухлин, хоча через 8-10 років в деяких випадках можуть загинути від лімфом (Olson et al., 1981; Porta et al., 2019).

Одночасно з наведеними даними ряд дослідників у дослідах з відтворення лейкозу великої рогатої худоби на лабораторних тваринах отримали негативні результати (Mammerickx et al., 1981). Важкість переносу лейкозу від одного виду тварини до іншого, так як від одного індивідуму іншому того ж виду, зумовлена, ймовірно, імунологічними особливостями організму. Відомі онковіруси птахів, мишей та щурів важко долають міжвидовий бар'єр (Han et al., 2020).

Лейкоз великої рогатої худоби не є специфічним лише для великої рогатої худоба, це інтерпретує передача вірусу вівцям та кролям 3 виявленням подібних клінічних, імунологічних та пато-морфологічних ознак, тому така схожість свідчить про можливу етіологічну спільність лейкозів ссавців, в тому числі й людини (Gao et al., 2020; Zyrianova \& Kovalchuk, 2020).

\section{Висновки}

1. Отже, введення в організм кролів клітин культури FLK-BLV викликає розвиток імунодефіцитного стану та стимулює синтез специфічних антитіл до циркулюючого в організмі провірусу лейкозу великої рогатої худоби, тому відтворення дії BLV в організмі кролів (як на лабораторній моделі) $є$ доцільним та економічно вигідним рішенням в експериментальній онкології.

2. Гістологічні зміни в органах дослідних кролів: крововиливи, скупчення лімфоцитів у тканинах селезінки, легень, серця, нирок та печінки вказують на реорганізацію організму, зумовлену лейкозним процесом.

3. Позитивні результати біопроби (виникнення інфекційного процесу, схожого до лейкозного) на клінічно здорових кролях при введенні крові, відібраної від заражених культурою клітин (FLK-BLV), що продукує вірус лейкозу великої рогатої худоби, свідчить про можливість подальшої репродукції BLV в гетерологічних живих організмах.

Перспективою подальших досліджень є детальне вивчення етіологічного зв'язку між лейкозом великої рогатої худоби та інших видів тварин, що дозволить використовувати кролів як модельних тварин для вивчення патогенетичних механізмів онкологічного процесу.

\section{References}

Acaite, J., Tamosiunas, V., Lukauskas, K., Milius, J., \& Pieskus, J. (2007). The eradication experience of enzootic bovine leukosis from Lithuania. Preventive veterinary medicine, 82(1-2), 83-89. doi: 10.1016/j.prevetmed.2007.05.010.

Alvarez, I., Gutiérrez, G., Gammella, M., Martínez, C., Politzki, R., González, C., Caviglia L., Carignano H., Fondevila N., Poli M., \& Trono, K. (2013). Evaluation of total white blood cell count as a marker for proviral load of bovine leukemia virus in dairy cattle from herds with a high seroprevalence of antibodies against bovine leukemia virus. American journal of veterinary research, 74(5), 744-749. doi: 10.2460/ajvr.74.5.744.

Barez, P-Y., De Brogniez, A., Carpentier, A., Gazon, H., Gillet, N., Gutiérrez, G., Hamaidia, M., Jacques, J-R., Perike, S., Neelature-Sriramareddy, S., Renotte, N., Staumont, B., Reichert, M., Trono, K., \& Willems, L. (2015). Recent Advances in BLV Research. Viruses, 7(11), 6080-6088. doi: 10.3390/v7112929.

Buehring, G. C., DeLaney, A., Shen, H., Chu, D. L., Razavian, N., Schwartz, D. A., Demkovich, Z. R., \& Bates, M. N. (2019). Bovine leukemia virus discovered in human blood. BMC infectious diseases, 19(1), 297. doi: 10.1186/s12879-019-3891-9.

Castellano, A., \& Goizueta, M. (2014). Valor Agregado Institucional: Captación de Valor Económico de Innovaciones Tecnológicas. In Trabajo presentado en el IV Congreso Regional de Economía Agraria y XLV reunión anual de la Asociación Argentina de Economía Agraria, 21.

Gao, A., Kouznetsova, V. L., \& Tsigelny, I. F. (2020). Bovine leukemia virus relation to human breast cancer: Meta-analysis. Microbial Pathogenesis, 149, 104417. doi: 10.1016/j.micpath.2020.104417.

Gulyukin, M. I., Kapustina, O. V., Ezdakova, I. Y., Valtsiferova, S. V., Stepanova, T. V., \& Anoyatbekov, M. (2019). Detection of specific antibodies of classes $\mathrm{G}$ and $\mathrm{M}$ to bovine leukemia virus in the blood serum. Voprosy virusologii, 64(4), 173-177. doi: 10.36233/0507-4088-2019-64-4-173-177.

Hamilton, V. T., Stone, D. M., \& Cantor, G. H. (2003). Translocation of the B cell receptor to lipid rafts is inhibited in B cells from BLV-infected, persistent lymphocytosis cattle. Virology, 315(1), 135-147. doi: 10.1016/S0042-6822(03)00522-1.

Han, S. H., Park, B. J., Ahn, H. S., Kim, Y. H., Go, H. J., Lee, J. B., Park, S., Song, C., Lee, S., Choi, Y., Choi, I. S. (2020). Cross-Species Transmission of Swine Hepatitis E Virus Genotype 3 to Rabbits. Viruses, 12(1), 53. doi: 10.3390/v12010053.

Kobayashi, T., Inagaki, Y., Ohnuki, N., Sato, R., Murakami, S., \& Imakawa, K. (2020). Increasing Bovine leukemia virus (BLV) proviral load is a risk factor for progression of Enzootic bovine leucosis: A prospec- 
tive study in Japan. Preventive veterinary medicine, 178, 104680. doi: 10.1016/j.prevetmed.2019.04.009.

Krasnikova, E. S., Bouchemla, F., Krasnikov, A. V., Radionov, R. V., \& Belyakova, A. S. (2019). The hematobiochemical status of Wistar rat line under the bovine leukemia virus experimental infection. Veterinary world, 12(3), 382. doi: 10.14202/vetworld.2019.382388.

Lomonaco, M., Alvarez, I., Martínez, C., Porta N., Merlini, R., Gutiérrez, G., \& Trono, K. (2014). Epidemiological features of BLV natural infection. Retrovirology, 11(1), 1-1. doi: 10.1186/1742-4690-11S1-P45.

Mammerickx, M., Portetelle, D., \& Burny, A. (1981). Experimental Cross-Transmissions of Bovine Leukemia Virus (BLV) between Several Animal Species. Zentralblatt Für Veterinärmedizin Reihe B, 28(1), 6981. doi: 10.1111/j.1439-0450.1981.tb01740.x.

Maresca, C., Costarelli, S., Dettori, A., Felici, A., Iscaro, C., \& Feliziani, F. (2015). Enzootic bovine leukosis: Report of eradication and surveillance measures in Italy over an 8-year period (2005-2012). Preventive veterinary medicine, 119(3-4), 222-226. doi: 10.1016/j.prevetmed.2015.02.024.

Martínez, C., Gutiérrez, G., Alvarez, I., Porta, N., Lomónaco, M., Wigdorovitz, A., Chacana, P., \& Trono, K. (2014). Egg yolk antibodies (IgY) against bovine leukemia virus. Retrovirology, 11(1), 1-1. doi: 10.1186/1742-4690-11-S1-P46.

Murakami, H., Yamada, T., Suzuki, M., Nakahara, Y., Suzuki, K., \& Sentsui, H. (2011). Bovine leukemia virus integration site selection in cattle that develop leukemia. Virus Research, 156(1-2), 107-112. doi: 10.1016/j.virusres.2011.01.004.

Nuotio, L., Rusanen, H., Sihvonen, L., \& Neuvonen, E. (2003). Eradication of enzootic bovine leukosis from Finland. Preventive veterinary medicine, 59(1-2), 4349. doi: 10.1016/S0167-5877(03)00057-6.

Olson, C., Kettmann, R., Burny, A., \& Kaja, R. (1981). Goat lymphosarcoma from bovine leukemia virus. Journal of the National Cancer Institute, 67(3), 671675. doi: 10.1093/jnci/67.3.671.

Ovcharenko, N. D., Kuchina, E. A., \& Tuzikova, R. V. (2013). Gistologicheskie i gistohimicheskie metody issledovanija : uchebnoe posobie. Barnaul: AltGU (in Russian).

Porta, N. G., Alvarez, I., Archilla, G. S., Ruiz, V., Abdala, A., \& Trono, K. (2019). Experimental infection of sheep with Bovine leukemia virus (BLV): Minimum dose of BLV-FLK cells and cell-free BLV and neutralization activity of natural antibodies. Revista Argentina de Microbiología, 51(4), 316-323. doi: 10.1016/j.ram.2019.01.004.

Rhodes, J. K., Pelzer, K. D., \& Johnson, Y. J. (2003). Economic implications of bovine leukemia virus infection in mid-Atlantic dairy herds. Journal of the American Veterinary Medical Association, 223(3), 346-352. doi: 10.2460/javma.2003.223.346.

Saldarriaga-Saldarriaga, A., González-Herrera, L. G., Londoño-Gil, M., Flórez, J. C. R., \& López-Herrera, A. (2020). Best linear model to explain variability in the growth in Blanco Orejinegro cattle and effect of the serological status for bovine viral diarrhea and bovine leukosis. Semina: Ciências Agrárias, 41(4), 1385-1398. doi: 10.5433/1679-0359.2020v41n4p1385.

Sentsui, H., Kono, Yu., Itohara, Sh., \& Ishino, S. (1988). Experimental infection of bovine leukemia virus in small laboratory animals. The Japanese Journal of Veterinary Science, 50(6), 1245-1251. doi: 10.1292/jvms 1939.50.1245.

Shabeykin, A. A., Gulyukin, A. M., Stepanova, T. V., Kozyreva, N. G., \& Ivanova, L. A. (2019, August). Risk assessment for interspecies transmission of enzootic bovine leukemia. In IOP Conference Series: Earth and Environmental Science, 315(4), 042036. doi: $10.1088 / 1755-1315 / 315 / 4 / 042036$.

Sihvonen, L. H. (2015). EFSA Panel on Animal Health and Welfare (AHAW). Enzootic bovine leukosis. EFSA Journal, 13(7), 4188. doi: 10.2903/j.efsa.2015.4188.

Trono, K. G., Pérez-Filgueira, D. M., Duffy, S., Borca, M. V., \& Carrillo, C. (2001). Seroprevalence of bovine leukemia virus in dairy cattle in Argentina: comparison of sensitivity and specificity of different detection methods. Veterinary microbiology, 83(3), 235-248. doi: 10.1016/S0378-1135(01)00420-5.

Zyrianova, I. M., \& Kovalchuk, S. N. (2020). Bovine leukemia virus tax gene/Tax protein polymorphism and its relation to Enzootic Bovine Leukosis. Virulence, 11(1), 80-87. doi: 10.1080/21505594.2019.1708051. 